NBER WORKING PAPER SERIES

\title{
INCORPORATING SCENARIO ANALYSIS INTO THE FEDERAL RESERVE'S POLICY STRATEGY AND COMMUNICATIONS
}

\author{
Michael D. Bordo \\ Andrew T. Levin \\ Mickey D. Levy \\ Working Paper 27369 \\ http://www.nber.org/papers/w27369 \\ NATIONAL BUREAU OF ECONOMIC RESEARCH \\ 1050 Massachusetts Avenue \\ Cambridge, MA 02138 \\ June 2020
}

Bordo is a professor of economics at Rutgers University, director of the Center for Monetary and Financial History, a research associate of the National Bureau of Economic Research (NBER), and a Distinguished Visiting Fellow at the Hoover Institution, Stanford University. Levin is a professor of economics at Dartmouth College, visiting scholar at the International Monetary Fund, scientific advisor to the central banks of Norway and Sweden, research associate of the NBER, and international research fellow of the Centre for Economic Policy Research (CEPR). Levy is chief economist for the Americas and Asia at Berenberg Capital Markets LLC. All three coauthors are members of the Shadow Open Market Committee. Roiana Reid was very helpful in contributing to the preparation of this paper. Nonetheless, the views expressed here are solely those of the authors and do not represent the views of any other person or institution. The views expressed herein are those of the authors and do not necessarily reflect the views of the National Bureau of Economic Research.

NBER working papers are circulated for discussion and comment purposes. They have not been peer-reviewed or been subject to the review by the NBER Board of Directors that accompanies official NBER publications.

(C) 2020 by Michael D. Bordo, Andrew T. Levin, and Mickey D. Levy. All rights reserved. Short sections of text, not to exceed two paragraphs, may be quoted without explicit permission provided that full credit, including $\odot$ notice, is given to the source. 
Incorporating Scenario Analysis into the Federal Reserve's Policy Strategy and Communications Michael D. Bordo, Andrew T. Levin, and Mickey D. Levy

NBER Working Paper No. 27369

June 2020

JEL No. E52,E58,N10,N11,N12

\author{
ABSTRACT \\ The U.S. economy currently faces a truly extraordinary degree of uncertainty as a consequence of \\ the COVID-19 pandemic. In these circumstances, the Federal Reserve could begin highlighting \\ alternative scenarios to illustrate key risks to the economic outlook, and such scenarios could \\ inform the Fed's policy strategy and public communications. In this paper, we present a set of \\ illustrative scenarios, including a baseline scenario with a rapid but incomplete recovery this year \\ (an upward-tilting checkmark), a benign scenario in which an effective cure or vaccine becomes \\ available and facilitates a nearly complete recovery by mid-2021, and a severely adverse scenario \\ involving persistently high unemployment and disinflationary pressures. Insights into these \\ scenarios can be drawn from key historical episodes, including the Spanish flu, the Great \\ Depression, the end of World War II, and the global financial crisis. We conclude by identifying \\ key challenges that the Federal Reserve might face in adjusting its monetary policy and \\ emergency credit facilities under each of these alternative scenarios. \\ Michael D. Bordo \\ Department of Economics \\ Rutgers University \\ New Jersey Hall \\ 75 Hamilton Street \\ New Brunswick, NJ 08901 \\ and NBER \\ bordo@econ.rutgers.edu \\ Andrew T. Levin \\ Department of Economics \\ Dartmouth College \\ 6106 Rockefeller Hall \\ Hanover, NH 03755 \\ and NBER \\ andrew.t.levin@dartmouth.edu \\ Mickey D. Levy \\ Berenberg Capital Markets LLC \\ 1251 Avenue of the Americas, 53rd Floor \\ New York, NY 10020 \\ USA \\ mickey.levy@berenberg-us.com
}




\section{Introduction}

The U.S. economy is beginning to reopen after undergoing a catastrophic disruption due to the COVID-19 pandemic and government shutdowns. Retail sales (excluding food) in April were nearly 30 percent lower than in February, and millions of Americans have lost their jobs, resulting in an extremely high unemployment rate of nearly 15 percent. Moreover, even that rate understates the total damage to the job market. All told, the recent collapse in economic activity has been reminiscent of the Great Depression but within a timeframe of weeks instead of years.

Looking forward, the uncertainty about the U.S. economic outlook is extraordinarily high, reflecting a very wide range of potential trajectories for the COVID-19 pandemic. A rapid recovery in economic activity and employment to pre-pandemic levels is possible, particularly if the accelerated development of vaccinates and/or antiviral medicines bears fruit.. However, public health experts have cautioned that a much longer time horizon might be required to obtain an effective vaccine or cure for the virus; in that case, even with the lifting of quarantine measures, many individuals might continue to engage in voluntary social distancing, leading to a more severe and protracted economic downturn.

Since the onset of the COVID-19 pandemic, the Federal Reserve has acted promptly and forcefully in carrying out its role as lender of last resort, taking unprecedented actions to avoid a financial crisis and sustain the supply of credit. With fiscal backing from the Congress and the U.S. Treasury, the Federal Reserve has launched emergency liquidity facilities that have prevented the pandemic from triggering a systemic financial crisis. The Fed is now conducting outright purchases of corporate securities (including bonds commonly classified as “junk”), direct lending to businesses, and purchases of state and municipal debt.

The Federal Reserve's monetary policy actions have also been extraordinary. During the first half of March, the Federal Open Market Committee (FOMC) reduced the target federal funds rate to zero and indicated that monetary policy will remain accommodative until the economy is back on track. Since that time, the FOMC has purchased about \$2 trillion in Treasury securities and agency mortgage-backed securities (MBS), and its balance sheet now exceeds $\$ 7$ trillion. With the short end of the yield curve pinned near zero, these actions have had only muted effects on longer-term Treasury yields, which serve as a benchmark for other credit rates; the 10-year Treasury yield is currently about 0.9 percent, less than half a percentage point below its end-February level.

Clarity about the Federal Reserve's policy strategy is likely to be significant in mitigating the economic and financial consequences of the COVID-19 pandemic. As America's central bank, the Federal Reserve is responsible for carrying out its mandate of fostering maximum employment and price stability as well as promoting the stability of the financial system. 
Figure 1: Illustrative Scenarios for the Trajectory of Real GDP

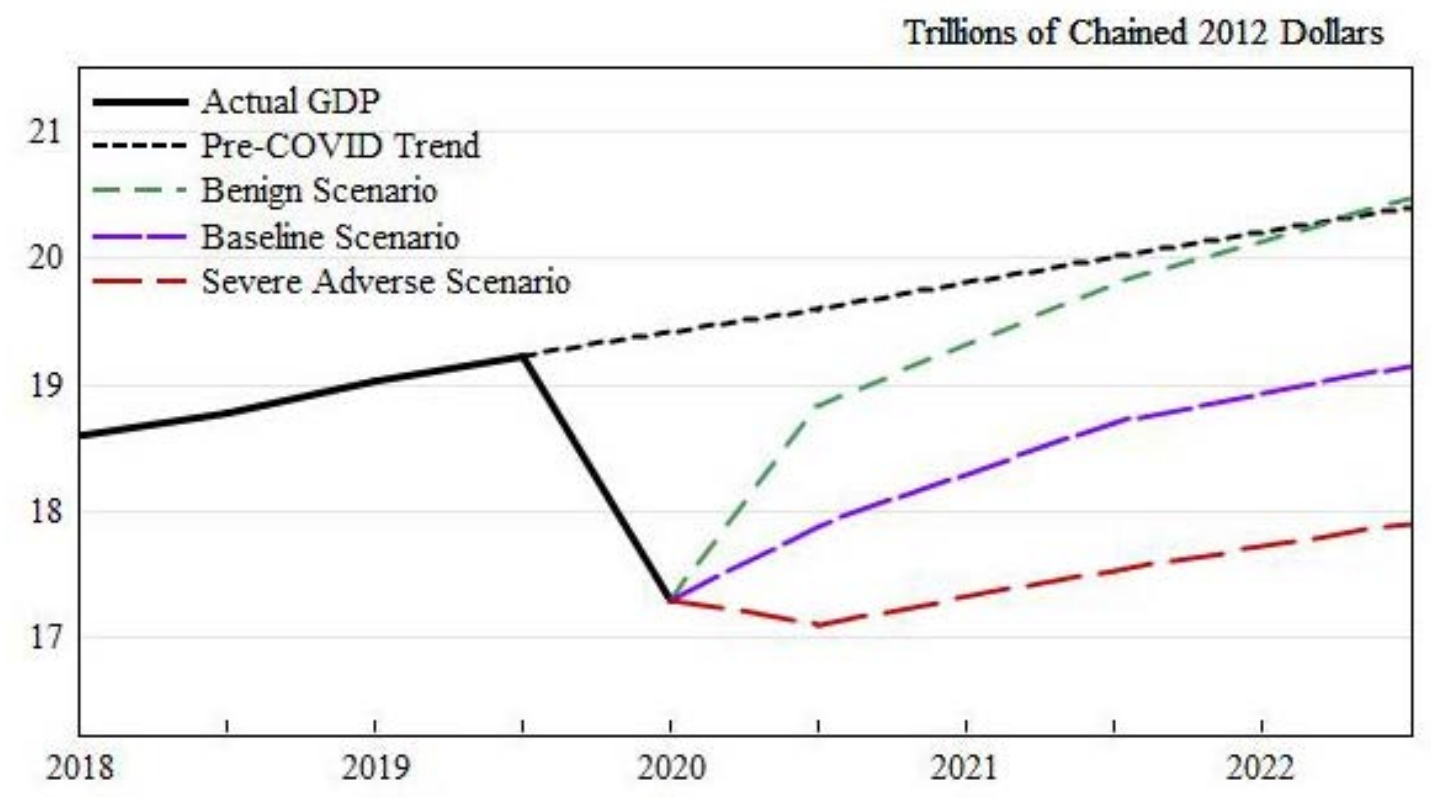

Source: U.S.Bureau of Economic Analysis, authors’ calculations

Its policy tools are now directly aimed at facilitating the supply of credit to households and businesses as well as states and municipalities. Consequently, the Fed's communications could play a key role in sustaining public confidence and fostering the recovery.

In these circumstances, the Federal Reserve could consider explaining its policy strategy by referring to alternative scenarios rather than focusing on a single benchmark projection. Such extraordinary uncertainty may be difficult to convey with "fan charts" around a baseline projection. Thus, it could be helpful for the Federal Reserve to use scenario analysis for identifying key risks to the economic outlook and explaining its plans for mitigating and addressing such risks.

In this note, we show how this approach could be implemented by describing the broad contours of a baseline projection that is bracketed by two plausible alternative scenarios. Figure 1 illustrates this approach for the trajectory of real GDP under the following three scenarios:

(1) In the baseline scenario, the U.S. economy exhibits a partial rebound this year, mainly reflecting re-employment in construction, manufacturing, and a portion of service-producing industries. Nonetheless, employment remains far below its pre-pandemic peak and recovers only slowly over coming years, while inflation remains well below the Fed's target.

(2) In the benign scenario, medical researchers develop an effective and widely available vaccine or cure, ending the pandemic and restoring confidence. Consequently, a robust recovery fosters rapid growth in economic activity and employment, and the economy returns close to its pre-pandemic trend path by the middle of next year. 
(3) In the severe adverse scenario, no effective vaccine or cure becomes available, and the threat of infection does not abate. Consequently, consumer and business sentiment wanes further, leading to sustained high unemployment, further business closures and widespread credit defaults, thereby triggering an adverse feedback loop between the real economy and the financial system as well as persistent deflationary pressures.

We provide additional perspective on these scenarios in light of several relevant historical episodes, including the Spanish flu pandemic of 1918-19, the Great Depression of the 1930s, and the economic transition at the end of World War II. We then highlight the distinct policy challenges that the Federal Reserve might face in adjusting its monetary policy and emergency credit facilities under each of these alternative scenarios. For example, in the benign scenario, the Fed might need to unwind its emergency actions very rapidly to avoid an undesired credit boom or undesired high inflation as in the wake of World War II. Conversely, in the severe adverse scenario, the Fed would be at a crossroads of either expanding its monetary toolbox or remaining on the sidelines as it did in the Great Depression.

\section{The Rationale for Alternative Scenarios}

Unlike normal periods, the uncertainty around the current economic outlook hinges on medical and public health concerns that may be difficult to capture with conventional macroeconomic models. ${ }^{1}$ In the face of such extreme uncertainty, the consideration of alternative scenarios could be helpful in weighing the relative benefits of alternative strategies, including potential unintended consequences and longer-run risks.

In effect, Fed officials may be viewed as analogous to a team of physicians, where the patient is the U.S. economy. In a complex medical situation, the patient needs a team of expert doctors, who examine an array of information to determine the appropriate course of treatment. That process involves extensive consultations with the patient and the patient's family to discuss the medical diagnosis, treatment plans, uncertainties, risks, and contingency plans. Such consultations need to be managed carefully to facilitate clear communications without unnecessarily alarming the patient. The Fed faces broadly similar challenges in engaging with the public and in reporting to the Congress (which is the Fed's boss).

The Federal Reserve currently frames its monetary policy in terms of a single benchmark projection of the economy, namely, the median of FOMC participants' individual assessments of the most likely trajectory for key macroeconomic indicators, including real GDP growth, the unemployment rate, headline inflation for personal consumption expenditures (PCE), core PCE

\footnotetext{
${ }^{1}$ Recent studies incorporating epidemiological factors into macroeconomic models include Atkeson (2020), Atkeson, Kopecky, and Zha (2020), Baqaee, Farhi, Mina, and Stock (2020, Coibion, Gorodnichenko, and Weber (2020), Gregory, Menzio, and Wiczer (2020), Eichenbaum, Rebelo, and Trabandt (2020), Fernandez-Villaverde and Jones (2020), Guerrieri, Lorenzoni, Straub, and Werning (2020), and Hall, Jones, and Klenow (2020).
} 
inflation, and the federal funds rate. ${ }^{2}$ These projections are released each quarter at the same time as the FOMC meeting statement and are then discussed at the Fed chairman's press conference, with further details published three weeks later in the Summary of Economic Projections (SEP) that accompanies the FOMC minutes. ${ }^{3}$ These SEP projections reflect each FOMC participant's individual judgment regarding the appropriate path of monetary policy. The chart showing the distribution of their assessments for the federal funds rate is commonly known as the "dot plot." However, the SEP does not include any projections for the size and composition of the Fed's balance sheet, even though the FOMC highlights balance sheet operations as a key element of its monetary toolbox.

The SEP conveys uncertainty about the economic outlook by reporting on FOMC participants' qualitative assessments about whether or not that uncertainty is elevated relative to "normal" and whether the risks to the outlook are judged to be "balanced", "tilted to the upside", or "tilted to the downside.” The SEP also includes tabulations of historical forecast errors for each key macroeconomic indicator; these tabulations are often referred to as "fan charts."

This focus on a single benchmark projection is not likely to be satisfactory for framing the Fed's policy strategy and contingency plans, especially amid current heightened risks and uncertainties. Consequently, the Federal Reserve could consider engaging in scenario analysis aimed at identifying specific risks to the economic outlook, and such analysis could be used in formulating and communicating its contingency plans for addressing such risks. ${ }^{4}$ Indeed, since the financial crisis of 2008-2009, the Fed has conducted annual stress tests of the largest financial institutions, and these evaluations have proven helpful for gauging each institution's capacity for coping with a severe adverse scenario and ensuring that it has a well-designed strategy for doing so.

Scenario analysis can be particularly advantageous when uncertainty is extraordinarily high due to factors that are not well captured by conventional econometric or statistical methods. In such circumstances, assigning definite probabilities to each of the plausible outcomes may not be practical. Economists commonly describe such circumstances as Knightian uncertainty, while others have simply referred to the "unknown unknowns." ${ }^{5}$ Lord Mervyn King has recently coined the term radical uncertainty and has specifically advocated that central banks should utilize a narrative approach to strategic planning and public communications in such

\footnotetext{
${ }^{2}$ The voting members of the FOMC include the governors of the Federal Reserve Board, the president of the New York Fed, and four of the other eleven Federal Reserve Bank presidents (who have voting membership on an annual rotating basis). However, SEP projections are submitted by all of these FOMC participants, including those who are not currently voting members.

${ }^{3}$ For each of these macroeconomic indicators, the Fed publishes the range of projections across FOMC participants and a "central tendency" interval that is calculated by excluding the highest three and the lowest three projections. 4 See Levin (2014, 2015) and Levy (2019).

${ }^{5}$ See Knight (1921) and Hansen and Sargent (2007). The phrase "known unknowns and unknown unknowns" was popularized by U.S. Secretary of Defense Donald Rumsfeld at a news briefing in 2002.
} 
circumstances; similarly, Nobel Prize winner Robert Shiller has highlighted the importance of narratives in determining major economic outcomes. ${ }^{6}$

Some officials might worry that more transparent risk assessments and contingency plans could undermine public confidence. But the health care analogy is helpful here: in a serious medical situation, the patient can easily imagine worst-case outcomes and become unduly anxious, confused, or depressed, and that stress tends to exacerbate the patient's condition. Therefore, an effective medical team consults carefully with the patient and the patient's family, and those consultations are conducive to better health outcomes and help speed the patient's recovery.

Similar lessons are evident from national defense and hurricane preparedness. In a military context, scenario analysis (informally known as "war games") have long played a key role in strategic planning. In that context, the analysis is closely held to protect sensitive national security information. By contrast, when meteorologists identify an incipient hurricane, weather forecasters give regular updates to the public about the range of potential trajectories implied by alternative forecasting models, and such information facilitates public preparedness and helps mitigate the extent of damage from the hurricane itself.

Some officials might also worry that publishing alternative scenarios could unduly constrain the Fed's policy flexibility. In practice, however, it will be readily apparent that such scenarios are intended to be illustrative rather than serving as binding commitments. The set of illustrative alternatives and the specific contours of each scenario can be updated regularly in light of incoming information, following essentially the same process that the FOMC currently uses in producing and publishing its quarterly outlook. Moreover, policymakers can easily highlight or downplay any particular scenario as its relative likelihood changes over time.

Moreover, scenario analysis would not have to constrain the Federal Reserve to follow any rigid strategy or rule. Rather, such an approach might prove helpful in facilitating the Fed's policy deliberations and enhance the clarity of its public communications. Indeed, explaining its policy strategy clearly might well foster public confidence more effectively than a conventional approach of making and explaining decisions on a "meeting-by-meeting" basis.

For example, once per quarter, the Fed could formulate and publish a set of alternative scenarios along with its baseline SEP projection. In addition to the macroeconomic variables currently included in the SEP, each scenario could indicate the Fed's assessment of appropriate monetary policy under that scenario. Such assessments could include the anticipated trajectory for the overall size and composition of the Fed's balance sheet, especially given that the federal funds rate is currently anchored near zero and the Fed is now engaged in open-ended asset purchases. The broad contours of those scenarios could be presented at the Fed chair's press conference, with further details disseminated in the SEP three weeks later.

\footnotetext{
${ }^{6}$ See Shiller (2019) and Kay and King (2020).
} 
Finally, our historical analysis of crises in section 4 below, To facilitate the effectiveness of such an approach, the Federal Reserve might also consider approaches to fostering a work environment that strongly encourages openness and outside-the-box thinking. Such steps could significantly enhance the Fed's ability to identify material risks to the economy and the financial system and to formulate strategic plans for avoiding or mitigating such risks.

\section{Illustrative Scenarios}

To help visualize how our proposed approach could be implemented, we now characterize the contours of a baseline scenario bracketed by two plausible alternative scenarios. The quantitative features of these scenarios are reported in Table 1 and are shown in Figures 2 and 3 as well as in Figure 1 above.

\subsection{Baseline Scenario}

Our baseline forecast of a moderate recovery assumes that the government manages a gradual, successful reopening of the economy, with ongoing limitations on public events and social distancing rules. While increasingly reliable testing for covid-19 gradually become more widely available, no effective vaccine or antiviral treatment becomes available before 2022. As a consequence, consumer and business confidence remain cautious, which contributes to a higher rate of personal saving and constrained business spending.

The shape of this economic recovery appears like an upward-tilted checkmark, with a sharp but incomplete rebound during the second half of 2020, followed by more gradual pace of recovery thereafter. Consequently, real GDP does not return to its pre-pandemic level until late 2022. After reaching a peak of around 15 percent, the unemployment rate is projected to recede to about 10 percent by the end of this year and declines more slowly to about $61 / 2$ percent by the end of 2022. Consumer spending, residential investment, and government purchases are the key drivers at the initial stages of recovery, while business fixed investment and exports lag substantially. These trends will be accompanied by a tilt away from globalization and mounting constraints on international capital flows.

Headline inflation turns negative and involves a temporary deflation reflecting the sharp decline in oil prices and downward pressure on prices of other goods and services during the sharp economic contraction, while core inflation goes to zero. The recovery in oil prices eliminates deflation but the core PCE price index remains close to zero (price stability) early in the recovery. Market and survey-based price expectations are consistent with flat prices but not any deflation. Inflation rises modestly in 2021-2022 but remains well below the Fed's $2 \%$ target due to weak aggregate demand and subdued wage growth. 


\section{Table 1: Macroeconomic Outcomes and Appropriate Policy Judgments under Three Illustrative Scenarios}

\begin{tabular}{|c|c|c|c|c|c|c|c|c|c|}
\hline & \multicolumn{3}{|c|}{ Baseline Scenario } & \multicolumn{3}{|c|}{ Benign Scenario } & \multicolumn{3}{|c|}{ Severe Adverse Scenario } \\
\hline & 2020 & 2021 & 2022 & 2020 & 2021 & 2022 & 2020 & 2021 & 2022 \\
\hline $\begin{array}{l}\text { Real GDP Growth } \\
\text { (Q4/Q4) }\end{array}$ & -7.0 & 4.5 & 2.5 & -2.0 & 5.0 & 3.5 & -11.0 & 2.5 & 2.0 \\
\hline $\begin{array}{l}\text { Unemployment Rate } \\
\text { (Q4 Average) }\end{array}$ & 10.0 & 8.0 & 6.5 & 7.0 & 5.0 & 4.0 & 14.0 & 16.0 & 15.0 \\
\hline $\begin{array}{l}\text { PCE Inflation Rate } \\
\text { (Q4/Q4) }\end{array}$ & 0.0 & 1.0 & 1.5 & 0.5 & 2.5 & 3.0 & 0.0 & 0.0 & -0.5 \\
\hline $\begin{array}{l}\text { Core PCE Inflation } \\
\text { (Q4/Q4) }\end{array}$ & 0.0 & 1.0 & 1.5 & 0.5 & 2.25 & 2.75 & 0.0 & 0.0 & -0.5 \\
\hline $\begin{array}{l}\text { Federal Funds Rate } \\
\text { (end of year) }\end{array}$ & 0.1 & 0.1 & 0.1 & 0.1 & 0.1 & 1.0 & 0.1 & 0.1 & 0.1 \\
\hline $\begin{array}{l}\text { FRS Balance Sheet } \\
\text { (\$ trillions) }\end{array}$ & 10 & 9 & 8 & 9 & 7 & 6 & 12 & 14 & 16 \\
\hline
\end{tabular}

Note: The balance sheet of the Federal Reserve System (FRS) includes all securities holdings as well as direct lending to businesses, states, and municipalities.

Despite the solid economic recovery in this baseline scenario, the unemployment rate remains more than double its pre-pandemic level, and inflation remains below the Fed's $2 \%$ target. In the current situation, the Fed funds rate is near zero and the Fed's balance sheet is rising rapidly, reflecting a combination of QE, Fed lending to businesses and its purchases of other debt securities. In this scenario, the Fed is presumed to keep its policy rate at zero while gradually reducing its balance sheet by allowing for run-off of its business lending, even as its Treasuries purchases rise due to its yield curve control program.

\subsection{Benign Scenario}

In this scenario, an effective vaccine or antiviral treatment becomes available over coming months, and hence the economy exhibits a $V$-shaped rebound as economic activity quickly returns to normal. With a resurgence of consumer confidence and business sentiment, aggregate demand is boosted by the release of pent-up consumer spending reinforced by the continuing effects of monetary and fiscal stimulus. Businesses ramp up their production and investment plans in response to stronger demand. New businesses offering innovative new products are created, and improved business production processes stemming from adjustments to the pandemic lift economic activity. Impediments to travel and global supply chains are eliminated, and U.S. international trade and financial flows return to normal. 
Figure 2: Illustrative Scenarios for Key Macroeconomic Indicators
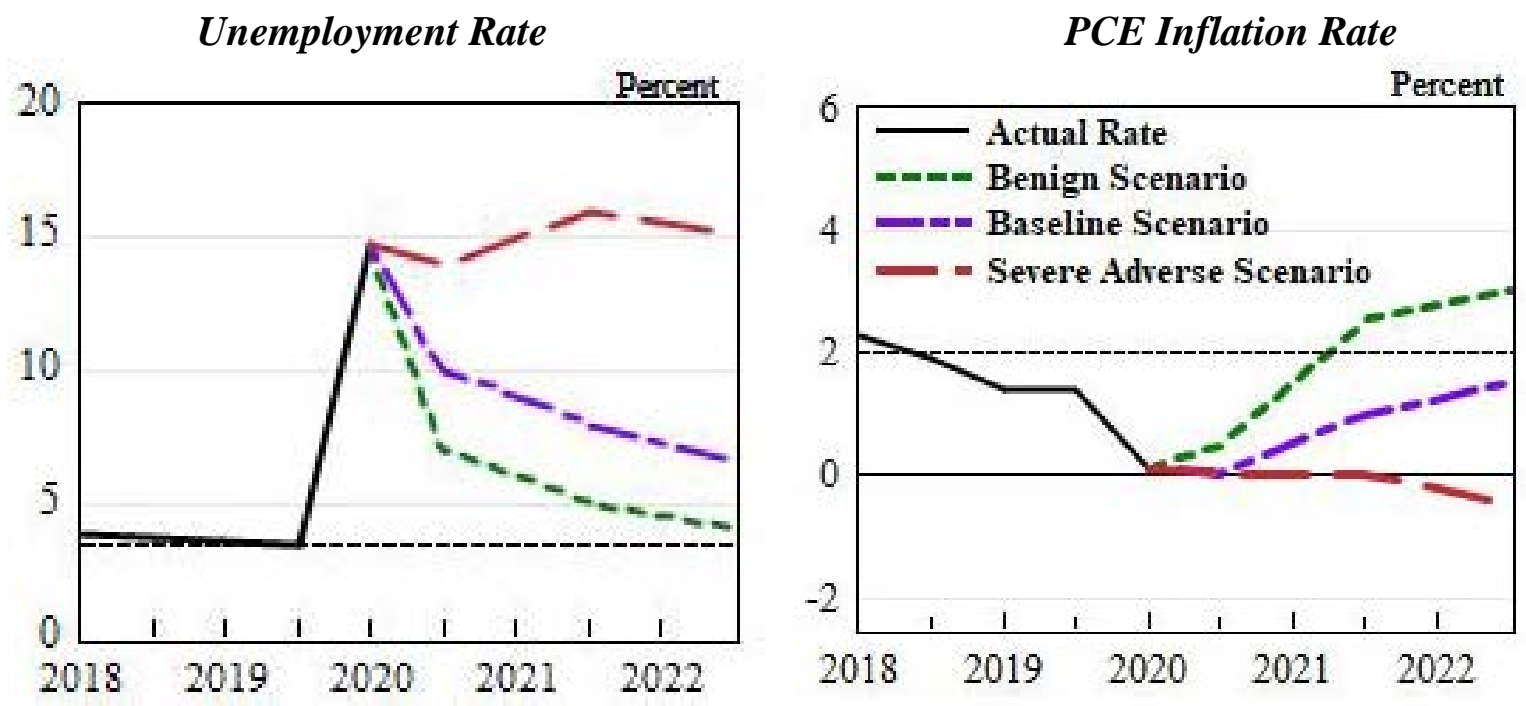

Source: U.S. Bureau of Labor Statistics, U.S. Bureau of Economic Analysis, authors' calculations.

Real GDP rebounds rapidly: its growth in the second half of 2020 nearly matches its contraction in the first half of the year, resulting in a net decline of $2 \%$ from fourth quarter 2019 to fourth quarter 2020. With sustained strong growth in place, real GDP regains its fourth quarter 2019 level midway through 2021 and continues to grow at a healthy pace through 2022.

Labor markets also experience a very rapid rebound. The largest portion of those unemployed by the pandemic and government shutdowns is rehired quickly, and the unemployment rate recedes to 7 percent by the end of this year and to 5 percent by late 2021. By the end of 2022, employment has nearly reached its pre-pandemic level. Global economic performance recoversquickly, as global output and trade regain prior levels, and oil prices rise to prepandemic levels. Global supply and distribution chains are slow to normalize, and production struggles to keep pace with the rapid rebound in aggregate demand. U.S. businesses selectively move production from foreign to domestic locations.

The re-tightening of labor markets and sharp acceleration in aggregate demand support stronger wage gains and a pickup in product prices. Consequently, core inflation rises to $23 / 4$ percent, while inflationary expectations shift upwards briskly. Higher oil prices, reflecting the strong domestic and global recovery, would likely add to headline inflation.

With a strong rebound pushing inflation well above the FOMC's 2 percent inflation target, the Fed is presumed to lift its policy rate in 2022 to 1 percent by the end of the year. Meanwhile, the Fed gradually unwinds its portfolio of direct business loans and allows the runoff of maturing corporate and municipal debt obligations. Nonetheless, the Fed's balance sheet still remains substantially larger than its pre-pandemic size of $\$ 4.5$ trillion. 
Figure 3: The Evolution of Monetary Policy under Alternative Scenarios

Target Federal Funds Rate

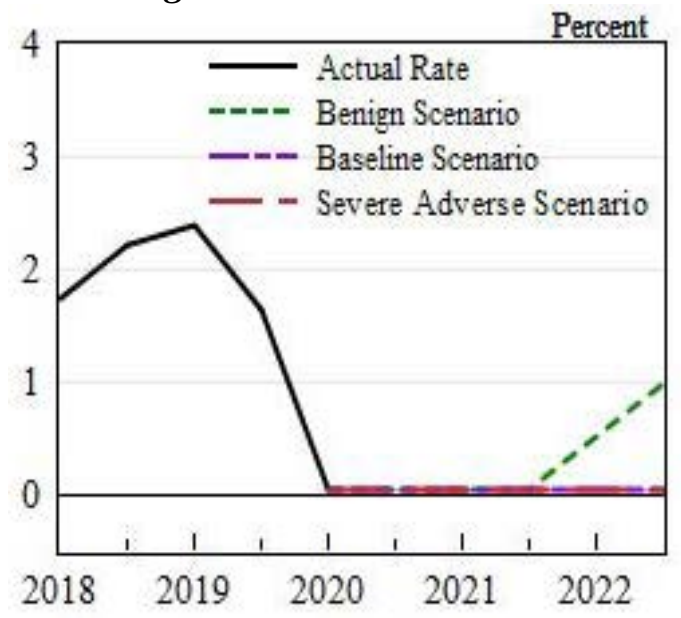

Federal Reserve Balance Sheet

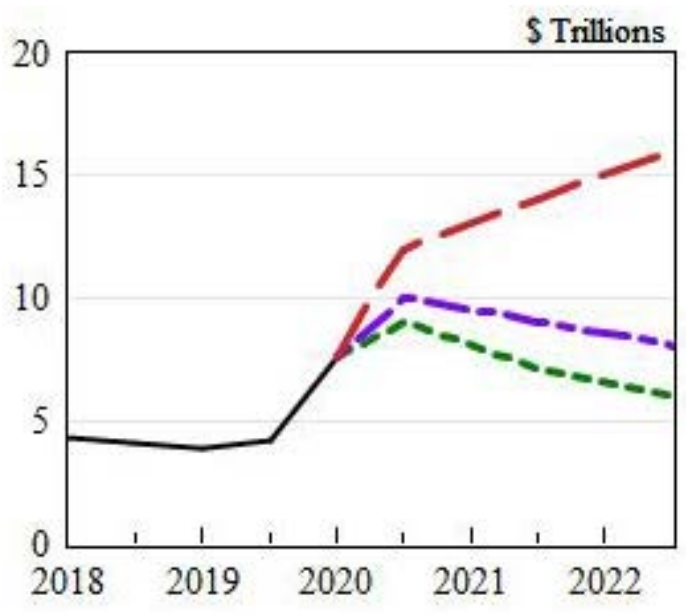

Source: Federal Reserve Board, authors’ calculations.

\subsection{Severe Adverse Scenario}

In this scenario, no effective vaccine or cure becomes available within the next two years, and the threat of infection does not abate. Consequently, the recovery of economic activity and employment is thwarted, triggering the onset of an adverse feedback loop between the real economy and the financial system that leaves the economy mired in conditions that echo the Great Depression of the 1930s.

With continuing high unemployment, consumer spending and business sentiment wane further. Persistently lower household income and business revenue induce large numbers of personal bankruptcies, business closures, and defaults on corporate debt obligations. Prices of core goods and services start declining, and deflationary expectations become ingrained in the outlook of financial market participants as well as consumers and businesses. Such deflation elevates the real cost of the debt burden for households and businesses, weighing further on risk spreads and credit conditions. That situation is exacerbated by adverse developments abroad, including ongoing disruptions in global supply chains, persistently weak demand for U.S. exports, and "risk-off” behavior triggered by foreign sovereign defaults and corporate bankruptcies.

In such circumstances, state and local government budgets become increasingly strapped as tax receipts plummet, state Medicaid rolls and expenditures expand, and demand for public services increases. Thus, the federal government faces pressure to serve as a continuing financial backstop for states and municipalities as well as a broad swath of private sector firms.

The precise contours of such a scenario cannot be anticipated with any precision, but it seems useful to illustrate its severity in terms of key macroeconomic variables. In particular, real GDP picks up only slightly over coming quarters and remains far below its pre-pandemic level even at 
the end of 2022. The unemployment rate remains above 15 percent through the end of 2022. The huge shortfall in aggregate demand induces substantial declines in the core PCE price index, and headline PCE price index drops further due to weakening commodity prices. Expectations of mild deflation lead consumers to postpone spending, and elevated personal saving partly offsets fiscal efforts to lift aggregate demand.

\section{Historical Lessons}

Extreme economic events like depressions, financial crises, and world wars require extreme policy actions. Pandemics like Covid-19 are associated with all three phenomena and differ significantly from garden variety cyclical fluctuations. In the face of a deep economic contraction and soaring unemployment, the Fed can learn important lessons from key historical episodes - including the Spanish flu pandemic, the onset of the Great Depression, the end of World War II, and the global financial crisis of 2007-2009_-as well as the process of economic and policy normalization following each of these shocks.

\subsection{The Spanish Flu Pandemic}

The world has seen many disastrous pandemics over recorded history. Among the very worst was the Black Death of 1331-1353, an outbreak of bacterial plague that killed between one-third and one-half of the population of Europe. The resulting shortage of labor led to a monumental change in the structure of Europe's society and economy, including the end of feudalism and the onset of the agricultural revolution and, eventually, the industrial revolution.

Although not nearly as lethal as the plague, the Spanish Flu of 1918-1919 has been the worst pandemic in modern history, causing 675,000 deaths in the United States and roughly 50 million deaths worldwide. Subsequent epidemics have been less destructive: the 1957 Asian flu, the 1968 Hong Kong flu, and more recently, SARS and Ebola.

The initial outbreak of Spanish flu occurred during spring 1918 in midwestern U.S. Army camps and then spread to Europe as U.S. troops crossed the ocean to join the fight. The return of the troops to the US in the fall of 2018 generated an even more deadly second wave, with the peak incidence occurring between September and December 1918 as the pandemic spread westward across the country. As in the current pandemic, the densely populated northeast was the region most severely affected. ${ }^{7}$

No vaccine or antiviral treatment was available at that time; indeed, virus strains were not identified as distinct from bacteria until nearly two decades later. In contrast to COVID-19

\footnotetext{
${ }^{7}$ Ferguson (2020) compares the Asian Flu epidemic to the Spanish Flu pandemic and the COVID-19 pandemic. However, the epidemiological analysis of Viboud et al. (2016) concluded that the excess fatalities from the Asian flu (beyond the mortality that would typically occur during the flu season at that time) was about 13,000 in the United States - far lower than the impact of the current pandemic.
} 
(which is most dangerous for middle-aged and older adults), the mortality rate from Spanish flu was highest for adults ages 20 to 40 years, and the fatalities comprised roughly 0.5 percent of the U.S. labor force at that time. ${ }^{8}$

Nonetheless, unlike the current pandemic, the Spanish Flu did not lead to a major U.S. recession; rather, the downturn was brief, and the economy exhibited a rapid V-shaped recovery. ${ }^{9}$ The NBER did record a recession over the period from August 1918 to April 1919, but the BalkeGordon data indicate that real GNP declined only slightly on a year-to-year basis. Industrial production fell 20 percent from July 1918 to January 1919, followed by a very rapid rebound. Other indicators -- including retail sales, purchases of consumer durables, and measures of employment -- also dropped sharply during autumn 1918 and then recovered briskly. For example, employment in New York fell 15 percent, but that decline only lasted a few months.

By contrast, the Spanish flu continued spreading across Europe and around the globe until early 1920. The U.K. economy experienced a more serious recession, while Barro and Ursua (2019) have analyzed a large panel of countries and found a 5 percent drop in global output.

As in the current pandemic, non-pharmaceutical interventions (NPI) were instituted in most cities, including the banning of large gatherings, closure of churches and synagogues, and admonitions regarding facemasks and hand-washing. However, no city had a total lockdown, so these NPIs did not directly affect manufacturers or other productive sectors of the economy. Indeed, the recent analysis of Correia, Luck and Verner (2020) finds that NPIs were effective in "flattening the curve" without impairing economic activity: Cities that imposed early and forceful NPIs (such as St. Louis) had lower mortality rates relative to other cities (such as Philadelphia) that did not adopt such measures.

In light of these patterns, why was the economic impact of the Spanish flu so mild compared to the economic collapse induced by the COVID-19 pandemic? Several considerations are relevant:

Structural Differences. As of 1918, about half of the U.S. population lived on farms and in small towns, and economic activity was dominated by agriculture, mining, and manufacturing. By contrast, only one-fifth of the population lives in rural areas, and the bulk of employment is in the retail trade and service sector, which are much more susceptible to disruption from a pandemic.

The Context of World War I. During 1917-1918, the U.S. government's share of economic activity was nearly 40 percent, as factories, mines, and shipyards operated at full capacity to meet its demands for materiel. ${ }^{10}$ Moreover, about 3 million men (about 6 percent of the U.S.

\footnotetext{
${ }^{8}$ The fatality rate for the 20 to 40 group was approximately $1 \%$ ( Gagnon et al 2013). Today the fatality rate is highest for people over 50. It reaches $11 \%$ for those aged 70-79. By comparison, according to the SIR models, were the covid -19 pandemic to go unchecked it would lead to a mortality shock similar or worse than 1918.

${ }^{9}$ See Bordo and Haubrich (2017) and Velde (2020).

${ }^{10}$ See Benmelech and Frydman (2020).
} 
labor force ages 18 to 45) were serving in the armed forces. Consequently, wartime production and employment likely dampened the negative economic shock, especially during the early stages of the pandemic.

Social Norms. Just prior to WWI, life expectancy at birth was around 50 years for males and 55 years for females, and rates of infant mortality and maternal mortality were extremely high. And the war itself was associated with massive loss of life, including 114,000 U.S. soldiers as well as millions of Europeans (both soldiers and civilians). Moreover, the dissemination of information was far more limited than the current context. ${ }^{11}$ In that context, the elevated death rate associated with the Spanish flu was seen as horrific but not cataclysmic. By contrast, life expectancy today is roughly $50 \%$ longer (76 years for males and 81 years for females). Many diseases that were previously associated with high fatalities are now treatable by antibiotics or vanquished by universal vaccination. Consequently, the prospect of hundreds of thousands or millions of fatalities from a pandemic is now viewed as far more catastrophic compared with a century ago. ${ }^{12}$

Mandated Lockdowns. As noted above, U.S. cities imposed some restrictions on large gatherings in 1918, but stores were not closed and factories were not shuttered. By contrast, a large swath of the U.S. economy has been closed by legal order over the past couple of months. Several new studies have integrated epidemiological features into conventional macroeconomic models; those model simulations suggest that the pandemic would cause a significant downturn and job losses even in the absence of any legal restrictions but conclude that the mandated lockdowns may account for a substantial fraction of the recent decline in U.S. economic activity. ${ }^{13}$ Nonetheless, the economy may not rebound fully even after those legal restrictions are lifted, especially if middle-aged and older adults remain cautious about the hazards of resuming their previous behavioral patterns.

\subsection{The Great Depression}

The Great Contraction of 1929-33 was the most severe U.S. economic downturn of the last century. It was likely precipitated because of policy failures in the US and elsewhere. The initial downturn in 1929 was triggered by the Federal Reserve's adherence to the flawed "real bills" doctrine as well as failures of corporate governance. ${ }^{14}$ The Fed's subsequent failure to act as a lender of last resort resulted in a series of disastrous banking panics starting in 1930 .

\footnotetext{
${ }^{11}$ Local newspapers played the role now occupied by social media, and the wire services were quite efficient in disseminating information. However, the Sedition Act of 1918 imposed a broad prohibition on any 'disloyal' communications that could undermine the war effort, and violations of that Act were subject to imprisonment for up to 25 years. Indeed, the term Spanish flu apparently reflects the fact that Spain was a neutral power that did not censor the press, and hence it became the first location where the outbreak of the pandemic was widely publicized.

12 See Ferguson (2020).

${ }^{13}$ See Atkeson (2020), Eichenbaum, Rebelo and Trabant (2020), and Jones and Villaverde (2020).

14 See Meltzer (2002) and Bordo and Prescott (2019).
} 
Consequently, a moderate recession turned into a severe and protracted depression. ${ }^{15}$ The unemployment rate rose above 25 percent, while real economic activity and aggregate prices fell more than 30 percent. Subsequent analysis has shown that the negative monetary shock was propagated to the real economy via rigid nominal wages. ${ }^{16}$ Other propagation mechanisms included debt deflation, the financial accelerator, and rising real interest rates. ${ }^{17}$ In the global economy, adherence to the gold standard both transmitted shocks between countries and also prevented mitigation by monetary and fiscal policy actions. ${ }^{18}$

The Great Contraction ended in March 1933 with actions undertaken by the incoming President, Franklin D. Roosevelt. The first was a banking holiday in early March when all the nation's commercial banks were closed for a week and then only sound banks were allowed to reopen. This ended the serious banking panic of 1932-33 by reassuring the public that their deposits were safe. The second was taking the US off the gold standard in April and removing 'golden fetters', that is, the constraints on expansionary monetary policy resulting from the gold standard. ${ }^{19}$ Recovery was fueled by a 60\% devaluation of the dollar in January 1934 as well as massive gold inflows that fueled monetary expansion.

The Fed did not play an active role during this period, partly due to its continuing adherence to the real bills doctrine. ${ }^{20}$ The Fed was granted enormous new powers in the 1935 Banking Act but did not use them. It was subsequently subordinated to the U.S. Treasury to keep interest rates low to facilitate the fiscal actions of the New Deal. There is considerable debate over whether those fiscal policies were key determinants of the recovery. ${ }^{21}$ Regardless, the global slump only fully ended with the rearmament leading to World War II.

The analogy of the Great Depression is highly relevant to understanding today's economic meltdown because of its depth and breadth and the propagation mechanisms and interactions between the financial system and the economy and the failure of the Fed to act. The collapse of aggregate demand, consumption, investment, labor markets, business failures, deflation, debt default, and collapse of the non-bank financial sector, involved at its most acute stage a decline of real GDP exceeding 10 percent. The collapse induced by the COVID-19 pandemic seems like the Great Depression on steroids; real GDP is projected to fall more than 10 percent (nonannualized rate) from March through June 2020.

\footnotetext{
${ }^{15}$ See Friedman and Schwartz (1963).

${ }^{16}$ See Bordo, Erceg, and Evans (2000).

17 See Fisher (1933), Bernanke (1983), and Hamilton (1992).

${ }^{18}$ See Friedman and Schwartz (1963) and Eichengreen (1992).

19 See Eichengreen (1992).

${ }^{20}$ See Meltzer (2003).

${ }^{21}$ See Romer (1992), Cole and Ohanian (2004), Eggertson (2008), and Jacobson, Leeper, and Preston (2016).
} 


\subsection{The End of WWII}

Government leaders and many others view the current U.S. government's efforts to stem the Covid-19 pandemic as equivalent to the total mobilization of resources during World War I and World War II. In both cases, the enemy was viewed as an existential threat, and all the country's resources were dedicated towards achieving victory. The U.S. involvement in World War I was short-lived but many of the policies adopted then were perfected on a much larger scale in World War II. ${ }^{22}$

During the war, resources of labor, goods, and production capacity were diverted from private peacetime uses to the government's military uses - a tradeoff that economists often characterize as "guns vs. butter." More than 16 million people (including conscripted individuals as well as volunteers), of whom 400,000 died in battle. Private-sector factories were mandated to transform from producing peacetime goods to war materiel, accomplished by a mix of direct regulations, rationing of goods and services, imposition of credit controls, and appeals to patriotism. ${ }^{23}$

The total cost of World War II represented about 175 percent of GDP as of $1945 .^{24}$ This massive increase in government expenditures was financed by a combination of taxes, bond issuance, and elevated inflation (commonly known as the "inflation tax"). ${ }^{25}$ The ratio of gross debt to GDP rose from about 40 percent in 1939 to around 120 percent in $1945 .{ }^{26}$ Following the end of the war, the gross debt declined steadily to a trough of about 35 percent of GDP in 1974, mainly due to a combination of rapid economic growth, mild inflation, and persistent primary surpluses.

This wartime fiscal expansion was accommodated by the Federal Reserve, which deferred to the Treasury Department in alleviating the costs of debt issuance by implementing low interest rate pegs (3/8 percent on short-term Treasuries and 21/2 percent on longer-term Treasuries). The inflationary consequences of this monetary policy were partially mitigated by wage and price controls; thus, wholesale prices rose at an annual rate of 4.5 percent from 1941 to 1945.

At the end of the war, policymakers feared a renewal of the deflation and depression of the 1930s, or even a more mild downturn similar to the aftermath of World War I. They ignored the burst of consumer spending and the surge in business investment that occurred once hostilities ceased and rationing ended. The accommodative low interest rate peg policy was continued, and once price controls were removed, inflation accelerated: Wholesale prices rose at an average annual pace of 15 percent from 1945 to 1948. Consequently, Chairman McCabe and other Fed

\footnotetext{
22 See Rockoff (2015).

${ }^{23}$ See Higgs (2006).

24 The cost was $\$ 307$ billion in current dollars and would be equivalent to nearly \$5 trillion now; see White (2020).

${ }^{25}$ Taxes covered 42 percent of the total cost, while the remainder was covered by bond issuance (34 percent) and the inflation tax (24 percent); see Friedman and Schwartz (1963).

${ }^{26}$ See Hall and Sargent (2020). Following the end of the war, the gross debt ratio was reduced to 35 percent, mainly via rapid economic growth combined with persistent primary surpluses; see Cochrane (2020).
} 
officials expressed growing concern over high and variable inflation, leading to rising tensions between the Federal Reserve and the Treasury. ${ }^{27}$

As the exigencies of the war began to fade and inflation pressures mounted, Fed officials started a campaign to free the Fed from the dominance of the Treasury and restore its independence, eliminating the interest rate peg and allowing the Fed to tighten monetary policy as needed to restore price stability. This outcome was finally achieved in the Federal Reserve - Treasury Accord of February 1951.

A key lesson from World War II is that once the pandemic passes, high inflation may be generated if the Fed does not unwind its emergency expansionary monetary policies. ${ }^{28} \mathrm{~A}$ similar lesson of over -extended monetary policy is provided by the second half of the 1960s, when the Fed kept interest rates too low to accommodate fiscal deficits resulting from domestic programs (The Great Society) and the intensification of the Vietnam War. Those actions ushered in a decade of high inflation that was finally ended by the Volcker Fed in 1980-82.

\subsection{The Global Financial Crisis}

Over the past decade, a huge number of studies have analyzed various aspects of the global financial crisis (GFC). Here we focus on four specific issues that seem particularly relevant under present circumstances: (1) the failure to identify the emerging risk of a financial crisis; (2) the absence of a clear strategy for serving as lender of last resort; (3) the ineffectiveness of the Fed's measures for providing additional monetary stimulus at the zero lower bound (ZLB); and (4) the sequence of major revisions to the Fed's exit strategy and the longer-term consequences for the size and composition of its balance sheet.

Risk Analysis. In contrast to the COVID-19 pandemic, the onset of the GFC was not a sudden or unforeseeable event. Indeed, as Shiller (2008) noted in an incisive commentary, numerous warnings were raised well in advance but were largely ignored by policymakers at the Fed and elsewhere. ${ }^{29}$ At a high-profile Fed conference, Rajan (2005) flagged the dangers of growing financial imbalances but was harshly criticized by other attendees. Unfortunately, such reactions were symptomatic of excessive insularity, complacency, and groupthink. ${ }^{30}$

During the early stages of the GFC, from autumn 2007 through early spring 2008, the FOMC reduced its federal funds rate target by a cumulative total of 3 percentage points. Some analysts

\footnotetext{
${ }^{27}$ See Meltzer (2003).

${ }^{28}$ Another risk is that the run-up in the debt to GDP ratio which may match or exceed the World War II level may not be reduced as readily as after the war.

${ }^{29}$ For example, in the second edition of his book on irrational exuberance, Shiller (2005) clearly stated that a catastrophic collapse of the housing boom could induce a worldwide recession, while Lewis (2010) highlights the financial market participants who succeeded in trading on that risk. Taylor (2007), Bordo and Landon-Lane (2013) and others have concluded that the Fed's monetary policy exacerbated the housing boom that precipitated the GFC. ${ }^{30}$ See Archer and Levin (2018).
} 
Figure 4: The Federal Reserve Staff's Assessment of Risks to the Economic Outlook as of September 10, 2008

\section{Greenbook Outlook}

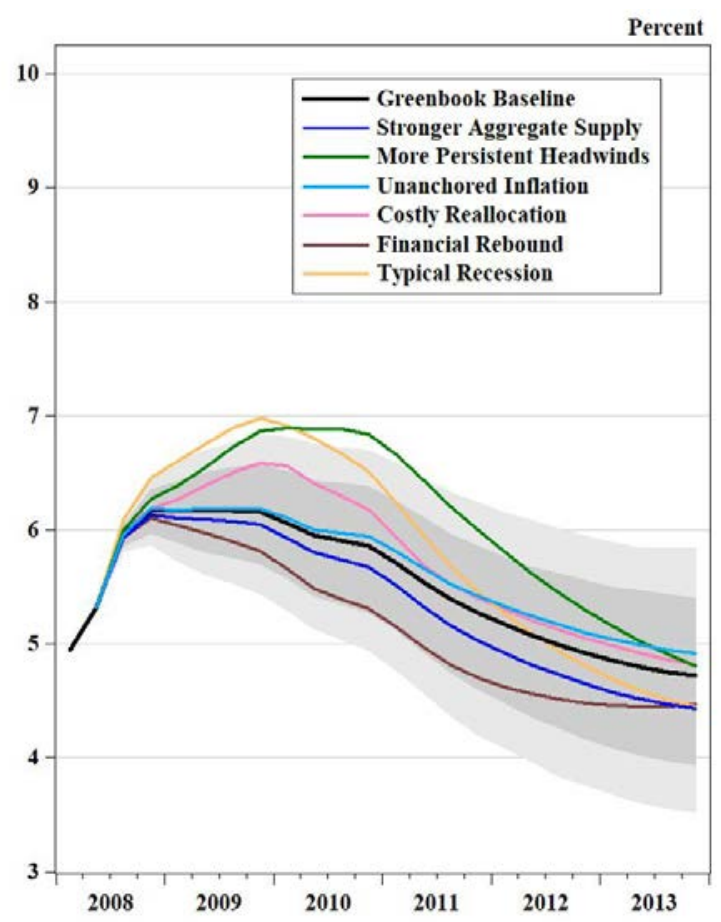

Actual Unemployment

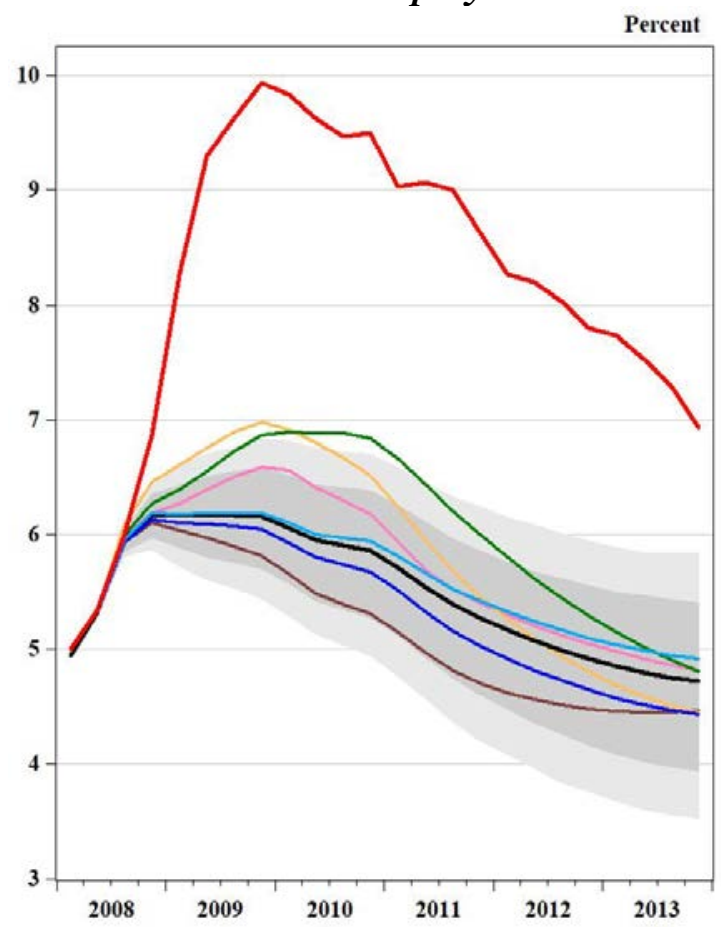

Note: The 70 percent and 95 percent confidence intervals generated by the FRB/US model are denoted by the dark and light shaded areas, respectively.

have concluded that the stance of monetary policy was still too tight. ${ }^{31}$ Nonetheless, at its meetings in June and August, the FOMC decided to stand pat in light of its concerns about upside risks to inflation. The next FOMC meeting was held on September 16, 2008-just one day after the failure of Lehman Brothers, the fourth largest U.S. investment bank and key counterparty to a huge array of outstanding financial transactions. At that juncture, one might reasonably have expected the FOMC to take decisive action while issuing a sober but reassuring press release. But in fact, the FOMC took no action and merely stated that "the downside risks to growth and the upside risks to inflation are both of significant concern to the Committee." Indeed, that outcome reflected a unanimous FOMC decision, i.e., ten ayes and no dissents.

The views of FOMC members at that September 2008 meeting were broadly in line with the background analysis provided by Federal Reserve Board staff. The staff outlook (which was called the "Greenbook") had been circulated a few days earlier, so the chief domestic economist provided an update at the FOMC meeting indicating that "...we're still expecting a very gradual pickup in GDP growth over the next year and a little more rapid pickup in 2010." ${ }^{32}$ Further

\footnotetext{
${ }^{31}$ See Hetzel (2012) and Bordo (2014).

${ }^{32}$ See FOMC Meeting Transcript, September 16, 2008, p.20.
} 
insight into the staff outlook can be garnered from the Greenbook itself, which was subsequently released to the public after a five-year lag.

In particular, the left panel of Figure 1 reproduces the staff's assessment of risks to the outlook for unemployment as presented in its September 2008 Greenbook. The shaded areas denote confidence intervals for the benchmark forecast (the "fan chart"), which indicated odds of 50:1 that the unemployment rate would remain below 7 percent. ${ }^{33}$ The alternative scenarios were intended to characterize a range of macroeconomic outcomes that would be broadly consistent with the model-based confidence intervals; these sources of risk included benign developments (such as a financial rebound) as well as adverse developments (such as persistent headwinds or a typical recession). By contrast, the right panel shows the actual evolution of the unemployment rate following the collapse of Lehman and the intensification of the GFC.

Evidently, the Fed staff's analysis was severely deficient in gauging the true magnitude of risks to the U.S. economic outlook, even as the financial system was teetering on the edge of collapse. This episode underscores one of our key recommendations in section 2 above, namely, the Federal Reserve needs to foster and sustain a work environment that encourages openness and outside-the-box thinking, so that Fed officials can clearly identify material risks to the economy and formulate plans for mitigating those risks.

Lender of Last Resort. Well before the onset of the GFC, observers regularly pointed out the Federal Reserve's lack of any clear and systematic strategy for serving as lender of last resort (LOLR) in a financial crisis, but unfortunately those warnings were not heeded. ${ }^{34}$

One consequence was that the Fed's actions during the GFC were widely seen as discretionary, opaque, and unfair instead of being viewed as transparent and even-handed. Controversy has swirled ever since then about why the Federal Reserve decided to rescue one investment bank (Bear Stearns) but not another (Lehman), and why it suddenly changed course thereafter to lend funds to two other investment banks (Goldman Sachs and Morgan Stanley). ${ }^{35}$ Similarly, the Fed's rescue of a major insurance firm (AIG) raised questions about why it wasn't providing similar assistant to other businesses. Consequently, the Fed was commonly subjected to criticism for helping out Wall Street while neglecting Main Street.

A related issue is that the Fed misdiagnosed the early stages of the GFC as reflecting a lack of liquidity rather than the risk of insolvency. ${ }^{36}$ The underlying problem reflected the difficulty of pricing securities backed by a pool of assets, whether mortgage loans, commercial paper issues, or credit card receivables. Pricing securities based on a pool of assets is difficult because the quality of individual components of the pool varies. Unless each component is individually

\footnotetext{
${ }^{33}$ These confidence intervals were obtained via stochastic simulations of the FRB/US model using shocks drawn from the estimated distribution of model residuals from 1987 to 2007 (the Great Moderation era).

${ }^{34}$ See Goodfriend and King (1988), Bordo (1990), and Meltzer (2003, 2010).

${ }^{35}$ See Ball (2016, 2018), Bernanke (2016), and Cheng and Wessel (2018).

${ }^{36}$ See Schwartz (2008) and Taylor and Williams (2008).
} 
examined and evaluated, no accurate price of the security can be determined. Consequently, the credit market was faced with assessing the risk of failure of financial firms whose portfolios were filled with complex derivatives whose value could no longer be ascertained. The credit market was thus plagued by the inability to determine which firms were insolvent, and hence lenders became increasingly unwilling to extend credit to borrowers who might not be creditworthy.

As financial strains intensified in spring 2008 and became a full-blown crisis after the collapse of Lehman, the Federal Reserve began intervening directly into securities markets and taking credit risk onto its balance sheet using its authority under section 13(3) of the Federal Reserve Act. As Goodfriend (2011) subsequently noted, such actions necessitated the picking of winners and losers - an intrinsically political choice best left to the fiscal authorities -- and hence posed substantial risks to the Fed's operational independence.

Monetary Stimulus. As the GFC subsided, the U.S. economy began to stabilize and the recession ended in mid-2009. The unemployment rate reached a peak of nearly 10 percent later that year and only subsided slowly over subsequent years (and even that decline partly reflected discouraged individuals dropping out of the workforce). With the federal funds rate pinned at zero starting in December 2008, the FOMC endeavored to foster a strong recovery using two "unconventional" tools for providing additional monetary stimulus: forward guidance about the target federal funds rate, and quantitative easing via large-scale purchases of Treasuries and agency mortgage-backed securities (MBS). Nonetheless, the subsequent recovery was painfully sluggish and took nearly a decade, the slowest U.S. recovery in the historical record, which in turn raises substantial doubts regarding the efficacy of both of those monetary policy tools. ${ }^{37}$

Exit Strategy. In spring 2009, the Fed began unwinding some of its short-term liquidity programs that had helped to stabilize disorderly markets, but it maintained its holdings of longerdated securities. However, most of the Fed's emergency liquidity programs were not closed until early 2010 -- well after financial strains had subsided. The Fed could have allowed those programs to end somewhat earlier but proceeded cautiously to avoid triggering a new bout of financial turmoil.

By contrast, the Fed's exit strategy for its balance sheet was relatively opaque and subject to a sequence of major reversals and revisions. Consequently, the actual evolution of the Fed's balance sheet was highly discretionary and unpredictable. As evident from the "taper tantrum" of 2013, that uncertainty contributed to elevated financial market volatility that likely hampered the effectiveness of the FOMC's monetary policy. ${ }^{38}$

\footnotetext{
${ }^{37}$ See Bordo and Haubrich (2017), Bordo and Levin (2019), Levin (2020), and Levin and Sinha (2020).

38 See Bordo and Levin (2019).
} 
Reinvestment Policy. In mid-2009, Fed officials indicated that large reserve balances could be reduced automatically due to ongoing principal repayments on its securities holdings. ${ }^{39}$ At its August 2010 meeting, however, the FOMC decided to prevent such shrinkage by reinvesting all principal repayments into new securities purchases. The FOMC subsequently agreed (in a near-unanimous decision in June 2011) that such reinvestments would be halted at the start of its policy normalization process, prior to implementing any increases in the target federal funds rate. In September 2014, however, the FOMC overturned that decision in a revised exit strategy that delinked the start of interest rate hikes from the onset of balance sheet normalization, and consistent with those revised principles, the reinvestment of principal repayments continued until autumn 2017 -- nearly two years after the liftoff of the target federal funds rate from the ZLB.

Sales of MBS. In June 2011, the FOMC reached a near-unanimous decision that sales of its MBS holdings would commence following the first increase in the target federal funds rate and that such holdings would be eliminated over a period of three to five years. ${ }^{40}$ However, the FOMC completely reversed that decision in its 2014 exit strategy, which stated that MBS sales were no longer anticipated; and, in fact, no such sales ever took place.

Indeed, the lack of transparency about the Fed's exit strategy continues to this day: The Federal Reserve Board has a public webpage entitled "History of the FOMC's Policy Normalization Discussions and Communications" that makes no reference to the June 2011 exit principles, as though that nearly-unanimous FOMC decision had never been made at all. ${ }^{41}$

\section{Current Policy Challenges}

Looking forward, lessons from historical crises are likely to be highly relevant as the Federal Reserve determines its strategy for adjusting its lender-of-last-resort programs and its monetary policy tools. We now consider such lessons in the context of the three illustrative scenarios presented in section 3 above.

In each of these illustrative scenarios, effective coordination and communication with the Congress and the Treasury could prove to be very helpful. For example, under current statutes, the extension or unwinding of many of the Fed's emergency programs - including the Fed's direct business lending initiative and its purchases of municipal debt and corporate securities -will hinge on the approval of the Secretary of the Treasury. Thus, formulating such plans in advance could help foster the Federal Reserve's mandated objectives of maximum employment and price stability and ensure that the Federal Reserve maintains its credibility and operational independence over time.

\footnotetext{
${ }^{39}$ See Bernanke (2009).

${ }^{40}$ See $h$ ttps://www.federalreserve.gov/monetarypolicy/fomcminutes20110622.htm.

${ }^{41}$ See https://www.federalreserve.gov/monetarypolicy/policy-normalization-discussions-communicationshistory.htm.
} 


\subsection{Lender-of-Last-Resort Programs}

In his recent testimony to the U.S. House Financial Services Committee and the U.S. Senate Budget Committee on May 18-19, Fed Chairman Powell stated: “The tools that the Federal Reserve is using under its 13(3) authority are for times of emergency, such as the ones we have been living through. When economic and financial conditions improve, we will put these tools back in the toolbox."

Some of these emergency programs are parallel to actions taken by the Federal Reserve at the height of the global financial crisis, including: providing short-term liquidity to primary dealers, commercial paper, and money market mutual funds; establishing a Term Asset-Backed Loan Facility (TALF) that purchases asset-backed securities; and extending U.S. dollar swap lines to an expanded list of global central banks. ${ }^{42}$ In addition, the Federal Reserve has broken new ground in using its 13(3) authority to engage in purchases of municipal debt securities, corporate bonds (investment-rated and certain sub-investment-rated categories) in both the primary and secondary markets, and direct lending to businesses via the Main Street Lending Program. (Tables A1 and A2 provide further details about those emergency actions.)

The Fed could specify the conditions under which each program is likely to be ended or tapered, weighing the objectives and benefits of each program against its costs and risks under each of the alternative scenarios. The Fed could also develop a strategy for communicating how and under what conditions the individual programs could be unwound, and the expected sequencing. In order to avoid unnecessary jarring impacts on finanical markets, clear communications could be particularly important for programs involving purchases of corporate and municipal debt securities. Moreover, the Fed could specifically flag key policy issues that might involve coordination with the U.S. Treasury and the Congress.

Short-Term Liquidity Programs. In both the baseline and benign scenarios, in which the economy recovers substantially while inflation remains subdued and financial markets quickly regain normal operations, the Fed could prepare to quickly unwind its emergency short-run liquidity provisions, including its Primary Dealer Credit Facility (PDFC), Commercial Paper Funding Facility (CPFF) and its Money Market Mutual Fund Facility (MMMF). The experience of the GFC shows that as extreme risk aversion dissipates and financial institutions resume normal operations, the Fed's short-term funding facilities are unlikely to be needed and hence could be unwound promptly.

Reducing the Fed's footprint in these short-term funding markets would likely be perceived as a healthy step toward normal functioning of those markets. The commercial paper market provides a good example of why these liquidity facilities could be unwound quickly: The yield spread of 3-month commercial paper over 3-month Treasury bills has already declined to normal following

\footnotetext{
${ }^{42}$ The Federal Reserve has also expanded the size and scope of its repurchase agreements in the domestic market
} and with other central banks. 
its temporary spike in March; that spike over 200 basis points was less than half the spread the occurred in late-2008.

To date, the CPFF's actual purchases of commercial paper have been quite small, totalling only a few billion dollars. Moreover, the narrow spreads and smooth operations of short-term funding markets suggest that the Fed's emergency liquidity support may no longer be necessary. That inference also applies to the MMMF and PDLF, which are emergency short-term funding facilities that could be discontinued under either the baseline scenario or the benign scenario.

TALF Program. At the height of the market dysfuncion in March 2020, the Fed announced that it would reinitiate TALF to provide support to the asset-backed securities (ABS) market, which primarily consists of securities collateralized by student loans, auto loans, revolving credit card balances, and SBA-guaranteed loans.

The original TALF was established at the height of the GFC, when the ABS market froze up and exacerbated the collapse in consumer and business lending. By contrast, the ABS market is currently functioning normally, even though the Fed has not yet implemented the new TALF. ABS spreads widened to about 3.4 percent in March, but that level was still far below the GFC peak of 10 percent, and spreads have subsequently receded to more normal levels.

Indeed, it seems doubtful that TALF would be an effective program at the present time. Consumer defaults are expected to soar as a consequence of very high unemployment, but in contrast to the GFC, commercial banks now have adequate capital buffers against consumer loan losses. Fed purchases of ABS under TALF might reduce the cost of credit for new borrowers but would be unlikely to help unemployed individuals who are unable to repay an existing student loan, car loan, or credit card balance.

Corporate Bonds. The Fed announced its Primary Market Corporate Credit Facility (PMCCF) and Secondary Market Corporate Credit Facility (SMCCF) at the height of the financial market dysfunction. Risk spreads on corporate bonds widened sharply in mid-March but still remained far below the peak reached during the GFC. Moreover, the sharp selloff of high yield bonds primarily reflected a transitory collapse in oil prices, which briefly dropped essentially to zero but have subsequently recovered.

Under the baseline and benign scenarios, business profits and cash flows recover, and hence further Fed purchases of corporate bonds might not be necessary. Moreover, it should be noted that the Fed's purchases and holdings of corporate bonds involve sizable risks and unintended consequences. Such purchases necessarily involve the allocation of credit, that is, picking winners and losers. Unlike the US Treasury market, the liquidity of corporate bonds varies significantly, and Fed purchases may affect prices of different bonds unevenly. By favoring some businesses over others, the Fed's bond purchases could inadvertently affect risk premia and influence the allocation of capital. 
The Fed also faces a risk that its corporate bond purchases could undermine broad public support for the Fed's actions, especially if such purchases are perceived as supporting large corporations and wealthy investors with little benefit to the rest of the economy. Moreover, sustained holdings of corporate bonds could present thorny governance issues, entangling the Federal Reserve in highly politicized issues of corporate decisionmaking.

Unwinding the Fed's holdings of corporate bonds could present far more complex challenges than the normalization of its balance sheet following the GFC. Accordingly, it could be very helpful for the Fed to set forth a clear and systematic strategy for doing so. In light of the risks of purchasing and holding corporate bonds over a sustained period, the Fed could place a high priority on reducing its exposure in the program. One potential element of that strategy could be to coordinate with the Treasury to swap its corporate bond holdings for an equal amount of Treasury securities of similar value and duration. ${ }^{43}$ Such a swap could prove helpful for normalizing the Fed's balance sheet and thereby sustaining its operational independence.

Municipal Debt. In response to dysfunction of the municipal bond market in March, reflecting concerns about significant financial shortfalls of state and municipal governments and the forced selling by large money managers, the Fed instituted a program to purchase short-term debt (up to 2 years maturity) of states and municipalities above certain sizes. It subsequently revised down the required size of municipalities whose debt is eligible for purchase. Similar to its corporate bond purchase program, the Fed's munis purchases necessarily involve "picking winners and losers.” To date, while the Fed's purchases have been relatively minor, municipal bond markets have returned to normal. The yield on a municipal bond ETF is now the same as before the pandemic. The financial challenges facing states and municipalities, and the federal government's role in providing financial support to those jurisdictions, will likely continue to be the subject of political debate for the foreseeable future.

Lending to Small \& Medium-Sized Firms. The Fed has just begun to ramp up direct lending to small and medium-sized businesses through its Main Street Lending Facility. Based on the Treasury's injection of capital, the Fed has the capacity to make about $\$ 2$ trillion of direct loans to businesses. As general business conditions and finances improve, some businesses will face ongoing debt service problems. Under each alternative scenario, the Fed's strategy would appropriately reflect the extent to which financial support to some businesses would be needed over an extended period and the most effective means of providing such support.

\footnotetext{
${ }^{43}$ In the aftermath of the GFC, the Federal Reserve had substantial holdings of MBS and debt securities issued by Fannie Mae and Freddie Mac, which were (and still are) under the conservatorship of the U.S. Treasury Department. Consequently, Plosser (2009, 2011, 2013) regularly advocated that the Federal Reserve engage in a swap with the U.S. Treasury, exchanging those agency-issued MBS and debt securities for Treasury securities of equal value.
} 


\subsection{Monetary Policy}

The FOMC's current target for the federal funds rate is 0 to 0.25 percent, and the Federal Reserve is engaged in open-ended purchases of agency MBS and Treasury securities. Since early March, the FOMC has purchased about \$2 trillion of these securities, and its balance sheet now exceeds $\$ 7$ trillion. With the short end of the yield curve pinned near zero, these actions have had muted effects on longer-term Treasury yields. For example, the 10-year Treasury yield currently stands at around 0.9 percent, less than half a percentage point below its end-February level. Looking ahead, the appropriate path of monetary policy would differ dramatically across the range of plausible scenarios.

Baseline Scenario. Recent Fed communications indicate that the FOMC is actively considering the initiation of yield curve control. However, targeting the shorter end of the yield curve would be unlikely to provide much new monetary stimulus, because the 2-year Treasury yield is already close to zero. But even targeting longer-term yields might prove ineffectual in stimulating the U.S. economy. As a point of reference, the Bank of Japan (BOJ) has maintained a ceiling of 0.1 percent on the 10-year Japanese government bond yield since September 2016, but that program failed to generate any acceleration of Japanese nominal GDP. Indeed, its core inflation rate was only 0.5 percent in 2019, practically identical to the level three years earlier and far below the BOJ's 2 percent inflation target.

The potential adverse consequences of yield curve control are also problematic. The Federal Reserve would shift from being a price taker to a price setter in the U.S. Treasury bond market the largest securities market in the world. In effect, maintaining such a peg would require a a commitment to purchase an unlimited amount of Treasury securities, which could result in a substantial deterioration in market functioning. Prior to the GFC, the Federal Reserve limited its holdings of any specific Treasury security to a fraction of the outstanding amount of that security, ranging from 15 percent for longer-term Treasury bonds to 35 percent for short-term Treasury bills. ${ }^{44}$ The Federal Reserve began relaxing those operational constraints in 2011, and its current purchases are subject to an upper limit of 70 percent of the outstanding amount of each Treasury security. ${ }^{45}$ However, even that limit might need to be relaxed in the context of a yield curve control program, especially in the context of upward pressure on bond yields. Such a heavy footprint in the Treasury market could impair the role of Treasury securities as a benchmark for other lending rates, with unfortunate repercussions for the functioning of credit markets and the overall pace of economic recovery.

Moreover, the eventual exit from yield curve control could be excruciatingly difficult, with pushback from fiscal policymakers as well as financial market participants. As noted above, following the end of World War II, the Federal Reserve continued to defer to the Treasury in

\footnotetext{
${ }^{44}$ See U.S. Government Accountability Office (2001), p.39.

${ }^{45}$ See https://www.newyorkfed.org/markets/treasury-reinvestments-purchases-faq.
} 
maintaining interest rate pegs; that arrangement contributed to high and volatile inflation outcomes during the late 1940s and was not ended until nearly six years after the end of the war.

Severe Adverse Scenario. Given its strong commitment to fostering economic recovery from the COVID-19 pandemic, it would be sensible to consider what monetary actions might become appropriate under a severe adverse scenario involving the continuation of extraordinarily high unemployment and the onset of deflation.

Expanded Securities Purchases and Direct Lending. If more severe risks materialize, the Fed could face pressures to expand its securities purchases and direct lending, perhaps even engaging in purchases of corporate equities or stakes in other private enterprises. ${ }^{46}$ However, it is doubtful whether stock purchases would provide substantial monetary stimulus. Such doubts seem reasonable in light of the inefficacy of the BOJ' stock purchase program; indeed, the BOJ currently owns more than three-fourths of all outstanding exchange-traded funds on the Japanese stock exchange, with little or no apparent effect on the broader economy.

Moreover, it should be recognized that purchases of corporate equities could directly entangle the Federal Reserve in complex and controversial issues of corporate governance and decisionmaking. As a substantial shareholder, the Fed would have fiduciary obligations to cast votes on executive compensation, resolutions on governance and corporate strategy, mergers and acquisitions, dividend payouts, and employee pension plans. ${ }^{47}$ Moreover, longer-term public ownership of private enterprises could pose a substantial risk of undermining the fundamental structure of the U.S. economy.

Digital Cash and Negative Rates. At the current juncture, Fed officials have essentially ruled out the use of negative interest rates as a policy tool. However, the previous analysis of Bordo and Levin (2019) has shown how the Federal Reserve could move promptly to establish a digital dollar, thereby strengthening its ability to provide additional monetary stimulus in a severe adverse scenario.

In particular, a digital dollar could serve as a practically costless medium of exchange and as a secure store of value that yields essentially the same rate of return as U.S. Treasury bills. Individuals and businesses would remain free to use paper cash if desired, but financial institutions would be disincentivized from engaging in arbitrage between paper cash and digital cash. Under such an arrangement, pushing short-term interest rates below zero could help steepen the yield curve, thereby facilitating the expansion of bank credit and fostering a more rapid recovery.

\footnotetext{
46 See Bernanke (2020).

${ }^{47}$ Capie (2010) documents the pitfalls of the Bank of England's experience in owning shares of private companies over many decades starting in the 1930s.
} 
Moreover, the Federal Reserve could fully insulate ordinary households and small businesses from incurring negative rates on their normal holdings of digital cash balances. ${ }^{48}$ With this design, the Federal Reserve would be able to effectively foster economic recovery and price stability without imposing any implicit taxes or fees on the typical household or small business. After all, the key rationale for reducing interest rates below zero would be to influence the incentives of wealthy investors and large financial firms—-not to penalize ordinary families or small businesses.

Benign Scenario. By contrast, the benign scenario is associated with a robust V-shaped recovery that could pose some risk of excessive inflation. In that scenario, the Fed might need to move promptly in withdrawing monetary stimulus as well as closing its emergency LOLR facilities. A moderate pickup in inflation would shore up the credibility of the FOMC's 2 percent inflation target and prevent more extreme overshooting outcomes. Consequently, it could be helpful for the FOMC to formulate and communicate contingency plans for adjusting its monetary policy stance in the event that inflation rises substantially higher than its 2 percent target.

\section{Concluding Remarks}

In light of historical experience, it is evident that dealing with "black swan" events requires a type of planning that is very different from the approaches the FOMC takes to policymaking in normal times. Today we are in the midst of an extraordinary crisis that has elements of several extreme events that have occurred over the past century. The Federal Reserve has responded to this crisis with an unprecedented array of emergency actions. Looking forward, the Fed will face crucial decisions in adjusting its monetary policy tools and its lender-of-last-resort facilities. Consequently, scenario analysis and contingency planning could be very helpful for sustaining public confidence, fostering the Federal Reserve's mandated goals of maximum employment and price stability, and ensuring that the Federal Reserve retains its operational independence over time.

\footnotetext{
${ }^{48}$ For example, an individual might hold funds in a single digital cash account, and moderate balances in that account (e.g., up to $\$ 25,000$ ) could be exempt from negative rates, while balances exceeding that limit would be subject to the negative interest rate. Of course, individuals and businesses would also be free to hold multiple digital cash accounts at various financial institution banks; in such instances, one of those accounts would need to be designated as the user's "primary" digital cash account, and the exemption would only apply to the funds held in that particular account.
} 
Table A1: The Federal Reserve's Emergency Policy Actions in Early Spring 2020

Monetary Policy

Target Federal Funds Rate

March 3 Target is reduced $50 \mathrm{bp}$ to a range of 1 to $1.25 \%$.

March 15 Target is reduced $100 \mathrm{bp}$ to a range of 0 to $0.25 \%$.

Large-Scale Asset Purchases

March 12 Broader Treasury purchases: As a part of its $\$ 60$ billion reserve management purchases, the Fed starts to purchase across a range of maturities to roughly match the maturity composition of Treasury securities outstanding and across eleven sectors.

March 15 QE: Fed to purchase at least $\$ 500$ billion of Treasury securities and at least $\$ 200$ billion of agency MBS. All principal payments of agency debt and agency MBS reinvested in agency MBS.

March 23 Open-ended QE: Fed will continue to purchase Treasury securities and agency MBS in the amounts needed to support smooth market functioning. Purchases will include agency commercial MBS.

\section{Lender of Last Resort Facilities}

Short-Term Liquidity

March 15 Primary credit rate lowered by 150 bp to $0.25 \%$, effective on March 16 . Depository institutions may borrow from the discount window for periods as long as 90 days.

March 15 Reserve requirement ratios reduced to 0\% effective on March 26.

March 15 Intraday credit to depository institutions encouraged on both a collateralized and uncollateralized basis.

March 17 Primary Dealer Credit Facility (PDCF) is established.

March 17 Commercial Paper Funding Facility (CPFF) is established.

March 18 Money Markey Mutual Fund Liquidity Facility (MMLF) is established.

\section{Municipal Credit}

March 20 Through the MMLF, the Federal Reserve Bank of Boston makes loans available to eligible financial institutions secured by certain high-quality assets purchased from single state and other tax-exempt municipal money market mutual funds.

March $23 \quad M M L F$ is expanded to include a wider range of securities, including municipal variable rate demand notes (VRDNs) and bank certificates of deposit.

March 23 CPFF is expanded to include high-quality, tax-exempt commercial paper as eligible securities, and pricing of the facility is reduced.

April 9 Municipal Liquidity Facility (MLF) is established. The facility will purchase up to $\$ 500$ billion of short term notes (up to 24 months maturity) directly from U.S. states (including the District of Columbia), U.S. counties with a population of at least two million residents, and U.S. cities with a population of at least one million residents.

April $27 \quad$ MLF is expanded by reducing population thresholds for eligible issuers and encompassing certain multistate entities allowed. Maximum term for eligible notes raised to 36 months.

June $3 \quad M L F$ is expanded further to include at least two municipalities or counties in each state and up to two other public enterprises as designated by each state's governor. 
Table A1 (contd.): The Federal Reserve’s Emergency Policy Actions in Early Spring 2020

\section{Lender of Last Resort Facilities (contd.)}

\section{Asset-Backed Securities}

March 23 Term Asset-Backed Securities Loan Facility (TALF) is established.

April 9 TALF is expanded to include the triple-A rated tranches of both outstanding commercial MBS and newly issued collateralized loan obligations as eligible collateral.

\section{Corporate Bonds}

March 23 Primary Market Corporate Credit Facility (PMCCF) is established to purchase investment-grade corporate bonds from eligible issuers and to provide loans directly to eligible borrowers.

March 23 Secondary Market Corporate Credit Facility (SMCCF) is established to purchase investmentgrade corporate bonds and corporate bond portfolios (exchange-traded funds) on the secondary market.

April 9 The size of the PMCCF and SMCCF is increased to $\$ 750$ billion, and the program is expanded to include issuers that were rated as investment grade as of March 22 but have subsequently been downgraded below investment grade but above a threshold of at least BB-/Ba3.

\section{Credit to Small \& Medium-Sized Firms}

April 6 Facility to provide term financing backed by the Small Business Administration's (SBA) Paycheck Protection Program (PPP) loans is established.

April 9 Main Street Lending Program (MSLP) is established. The program offers 4-year loans to companies employing up to 10,000 workers or with revenues of less than $\$ 2.5$ billion, with interest and principal payments deferred for one year. Eligible banks may originate new Main Street loans or use Main Street loans to increase the size of existing loans to businesses. Banks will retain a 5 percent share, selling the remaining 95 percent to the MSLP facility, which will purchase up to $\$ 600$ billion of loans.

April 30 The scope and eligibility terms of the MSLP are expanded. A third loan option is created, with increased risk sharing by lenders for borrowers with greater leverage (priority loans). Firms with up to 15,000 employees or up to $\$ 5$ billion in annual revenue are now eligible. The minimum loan size for "new" and "priority" loan options lowered to $\$ 500,000$ from $\$ 1$ million.

\section{Global U.S. Dollar Liquidity}

March 15 Agreement with Bank of Canada, Bank of England, Bank of Japan, European Central Bank, and Swiss National Bank to reduce the pricing for standing U.S. dollar liquidity swap arrangements by $25 \mathrm{bp}$. Also agreed to begin offering U.S. dollars weekly in each jurisdiction with an 84-day maturity, in addition to the 1-week maturity operations currently offered.

March 20 Frequency of maturity operations increased from weekly to daily.

March 19 U.S. dollar liquidity arrangements with central banks of Australia, Brazil, Denmark, Korea, Mexico, New Zealand, Norway, Singapore, and Sweden, to continue for at least six months.

March 31 Foreign and international monetary authorities (FIMA) repo facility is established. 


\section{Appendix Table A2: Recent Changes in the Federal Reserve's Balance Sheet}

$$
\text { (billions of dollars) }
$$

\begin{tabular}{|c|c|c|c|c|}
\hline & March 11 & June 3 & Change & $\begin{array}{c}\text { Percent } \\
\text { Contribution } \\
\end{array}$ \\
\hline Total & 4,272 & 7,213 & 2,941 & 100 \\
\hline \multicolumn{5}{|l|}{ Securities Held Outright } \\
\hline Treasuries & 2,523 & 4,134 & 1,611 & 55 \\
\hline Agency MBS & 1,372 & 1,836 & 464 & 16 \\
\hline \multicolumn{5}{|l|}{ Credit Facilities } \\
\hline Primary Credit to Depository Institutions & 0 & 11 & 11 & 0 \\
\hline Primary Dealer Credit Facility & 0 & 9 & 9 & 0 \\
\hline Money Market Mutual Fund Liquidity Facility & 0 & 30 & 30 & 1 \\
\hline Commercial Paper Funding Facility & 0 & 13 & 13 & 0 \\
\hline Corporate Credit Facility & 0 & 36 & 36 & 1 \\
\hline Paycheck Protection Program Liquidity Facility & 0 & 55 & 55 & 2 \\
\hline Municipal Liquidity Facility & 0 & 16 & 16 & 0 \\
\hline Main Street Lending Facility & 0 & 0 & 0 & 0 \\
\hline Liquidity Swaps with Foreign Central Banks & 0 & 447 & 447 & 15 \\
\hline
\end{tabular}

Source: Federal Reserve Board, authors' calculations. 


\section{References}

Archer, David, and Levin, Andrew (2019). “Robust Design Principles for Monetary Policy Committees.” In: J. Simon (ed.), Reserve Bank of Australia Annual Conference Volume. pp.233-251.

Atkeson, Andrew (2020). "What Will Be the Economic Impact of COVID-19 in the US? Rough Estimates of Disease Scenarios.” NBER Working Paper 26867, March.

Atkeson, Andrew, Kopecky, Karen, and Zha, Tao (2020). “What will be the Economic Impact of COVID-19 in the US? Rough estimates of disease scenarios? NBER Working Paper 27355, March.

Ball, Laurence (2016). “The Fed and Lehman Brothers.” NBER Working Paper 22410, July.

Ball, Laurence (2018). The Fed and Lehman Brothers: Setting the Record Straight on a Financial Disaster. Cambridge University Press.

Baqaee, David, Farhi, Emmanuel, Mina, Michael, and Stock, James (2020). "Reopening Scenarios.” NBER Working Paper 27244, May.

Barro, Robert (2020). "Non-Pharmaceutical Interventions and Mortality in U.S. Cities during the Great Influenza Pandemic, 1918-1919.” NBER Working Paper 27049, April.

Barro, Robert, Ursua, Jose, and Weng, Joanna (2020). “ The Coronavirus and the Great Influenza Pandemic-Lessons from the 'Spanish Flu' for the Coronavirus's Potential Effects on Mortality and Economic Activity.” National Bureau of Economic Research Working Paper 26866, March.

Benmmelech, Efraim and Frydman, Carola (2020) 'The 1918 Influenza did not kill the US Economy.” VOxEU, April.

Bernanke, Ben (1983). “ Non Monetary Effects of the Financial Crisis in Propagation of The Great Depression” American Economic Review 73:3, pp 257-271.

Bernanke, Ben (2016). “Ending Too Big to Fail: What’s the right approach?” Brookings Institution blog, May 13. Available at: https://www.brookings.edu/blog/benbernanke/2016/05/13/ending-too-big-to-fail-whats-the-right-approach/

Bordo, Michael (1990). “The Lender of Last Resort: Alternative Views and Historical Experience.” Economic Review, Federal Reserve Bank of Richmond, January/February.

Bordo, Michael (2014). “ The Federal Reserve’s Role: Actions Before, During, and After the 2008 Panic in the Historical Context of the Great Contraction” chapter 6 in Across The Great Divide: New Perspectives on the Financial Crisis. (eds) Martin N. Baily and John B. Taylor . Stanford: Hoover Insitution Press. 
Bordo, Michael, and Landon-Lane, John (2013). "Does Expansionary Monetary Policy Cause Asset Price Booms: Some Historical and Empirical Evidence.” NBER Working Paper 19585.

Bordo, Michael, Erceg, Christopher, and Evans, Charles (2000). Money, Sticky Wages, and the Great Depression.” American Economic Review December 2000.

Bordo, Michael and Joseph Haubrich( 2017) " Deep Recessions, Fast Recoveries and Financial Crisis: Evidence from the American Record” Economic Inquiry 55:1, pp.527-547.

Bordo, Michael and Andrew Levin (2017). "Central Bank Digital Currency and the Future of Monetary Policy.” NBER Working Paper 23711. Published in: Michael Bordo, John Cochrane, and Amit Seru (eds.), The Structural Foundations of Monetary Policy. 2018. Stanford, CA: Hoover Institution Press.

Bordo, Michael and Andrew Levin (2019). “U.S. Digital Cash: Principles \& Practical Steps.” Cato Journal 39:383-405.

Bordo, Michael and Prescott, Edward Jr. (2019) "Federal Reserve Structure, Economic Ideas and Monetary and Financial Policy.” NBER Working Paper 26098.

Capie, Forrest (2010). The Bank of England: 1950s to 1979. Cambridge University Press. Cespedes, Luis, Chang, Roberto, and Velasco, Andres (2020). "The Macroeconomics of a Pandemic: A Minimalist Model.” NBER Working Paper 27228, May.

Cheng, Jeffrey and Wessel, David (2018). "Ten years after the financial crisis: Reflections by Bernanke, Geithner and Paulson.” Brookings Upfront Blog, September 19. Available at: https://www.brookinqs.edu/bloq/up-front/2018/09/19/reflections-by-bernanke-geithner-and-paulson/

Cochrane, John (2020). The Fiscal Theory of the Price Level. Manuscript, Hoover Institution.

Coibion, Olivier, Gorodnichenko, Yuriy, and Weber, Michael (2020). "The Cost of the COVID-19 Crisis: Lockdowns, Macroeconomic Expectations, and Consumer Spending.” NBER Working Paper 27141, May.

Cole, Harold and Ohanian, Lee (2004). " New Deal Policies and the Persistence of the Great Depression: A General Equilibrium Analysis.” Journal of Political Economy 112:4, pp 779-84.

Correia, S., Luck, S., and Verner, E. (2020) “ Pandemics Depress the Economy, Public Health Interventions Do Not : Evidence from the 1918 Flu.” Federal Reserve Bank of New York Working Paper.

Eggertson, Gauti (2008) “ Great Expectations and the End of the Depression.” American Economic Review 98:4, pp.1476-1516.

Eichengreen, Barry (1992). Golden Fetters. New York: Oxford University Press. 
Eichenbaum, Martin, Rebelo, Sergio, and Trabant, Mathias (2020) “ The Macroeconomics of Epidemics.” NBER Working Paper 26882, March.

Federal Reserve Board (2020). "2020 Supervisory Scenarios for Annual Stress Tests Required Under the Dodd-Frank Act Stress Testing Rules and the Capital Plan Rule.” Available at: https://www.federalreserve.gov/newsevents/pressreleases/files/bcreg20200206a1.pdf.

Ferguson, Niall (2020). “ 1918, 1957, 2020 : Big Pandemics and Their Economic, Social, and Political Consequences.’ Manuscript, Hoover Institution. May

Fernandez-Villaverde, Jesus, and Jones, Charles (2020). "Estimating and Simulating a SIRD Model of Covid-19 for Many Countries, States, and Cities.” Manuscript, Stanford University, May.

Fisher, Irving (1933) The Debt Deflation Theory of Great Depressions. Econometrica Friedman, Milton, and Schwartz, Anna (1963). A Monetary History of the United States, 1867 to 1963. Princeton, NJ: Princeton University Press.

Gagnon, Alain, Miller, Matthew, Hallman, Stacey, Bourbeau, Robert, Herring, Ann, and Madrenas, David (2018). “Age-Specific Mortality During the 1918 Influenza Pandemic: Unravelling the Mystery of High Young Adult Mortality” PLOS One 8:8, August.

Goodfriend, Marvin, and King, Robert (1988). "Financial Deregulation, Monetary Policy, and Central Banking.” In: Haraf, W. and Kushmeider, R., editors, Restructuring Banking and Financial Services in America. American Enterprise Institute.

Goodfriend, Marvin (2011). "Central Banking in the Credit Turmoil: An Assessment of Federal Reserve Practices.” Journal of Monetary Economics 58(1), pp.1-12.

U.S. Government Accountability Office (2001). Debt Management: Insights and Tools from Selected Nations. Available at: https://www.gao.gov/assets/240/233066.pdf.

Gregory, Victoria, Menzio, Guido, and Wiczer, David (2020). "Pandemic Recession: L or V-Shaped?” NBER Working Paper 27105, May.

Guerrieri, Veronica, Lorenzoni, Veronica, Straub, Ludwig, and Werning, Iván (2020). "Macroeconomic Implications of COVID-19: Can Negative Supply Shocks Cause Demand Shortages?” NBER Working Paper 26918, April.

Hall, George, and Sargent, Thomas (2020) “ Debt and Taxes in Eight U.S. Wars and Two Insurrections.” Handbook of Historical Economics.

Hall, Robert, Jones, Charles, and Klenow, Peter (2020). “Trading Off Consumption and COVID-19 Deaths.” NBER Working Paper 27340, June. 
Hamilton, James (1992). "Was The Deflation During The Great Depression Anticipated? Evidence from the Commodity Futures Market?” American Economic Review 82:1, pp. 157-178.

Hansen, Lars and Sargent, Thomas (2007). Robustness. Princeton, NJ: Princeton Univ. Press.

Robert Hetzel (2012) The Great Recession: Market Failure or Policy Failure? New York: Cambridge University Press.

Higgs, Robert (2006). Depression,,War and Cold War: Studies in Political Economy. New York: Cambridge University Press.

Jacobson, Margaret, Leeper, Eric, and Preston, Bruce (2016). “The Recovery of 1933.” Manuscript, Indiana University.

Kay, John and King, Mervyn (2020). Decision Making Beyond the Numbers.

New York: W.W. Norton Press.

Levin, Andrew (2014). "The Design and Communication of Systematic Monetary Policy Strategies.” Journal of Economic Dynamics and Control, 49:52-69.

Levin, Andrew (2015). "What Monetary Policymakers Can Learn from Weather Forecasters." Available at: https://internationalbanker.com/banking/central-bankers-can-learn-weatherforecasters/.

Levin, Andrew (2020). "Discussion: The Case for Implementing Effective Negative Interest Rate Policy.” In: Strategies for Monetary Policy: A Policy Conference. Hoover Institution Press.

Levin, Andrew and Sinha, Arunima (2020). "Pitfalls of Makeup Strategies for Mitigating the Effective Lower Bound.” Cato Journal 40:2.

Levy, Mickey (2017). "Why Have the Fed's Policies Failed to Stimulate the Economy?” Cato Journal, Vol 37, No. 1.

Levy, Mickey (2019). “The Fed and Financial Markets: Suggestions to Improve an Unhealthy Relationship.” In: Strategies for Monetary Policy: A Policy Conference. Hoover Institution Press.

Lewis, Michael (2010). The Big Short: Inside the Doomsday Machine. W.W. Norton Press.

Meltzer, Alan (2003). A History of the Federal Reserve, Volume 1. University of Chicago Press.

Meltzer, Alan (2010). A History of the Federal Reserve, Volume 2. University of Chicago Press.

Plosser, Charles (2009). "Ensuring Sound Monetary Policy in the Aftermath of Crisis."

Speech at the U.S. Monetary Policy Forum, February 27. Available at:

https://www.philadelphiafed.org/publications/speeches/plosser. 
Plosser, Charles (2011). "Exit.” Speech given to the Shadow Open Market Committee, March 25. Available at: https://www.philadelphiafed.org/publications/speeches/plosser.

Plosser, Charles (2013). “A Limited Central Bank.” Cato Journal, 34:1-9.

Rajan, Raghuram (2005). “Has Financial Development Made the World Riskier?”

Economic Review, Federal Reserve Bank of Kansas City, pp. 313-369.

Rockoff, Hugh (2012). The American Way of War: War and the U.S. Economy from the Spanish American War to the Persian Gulf War. Cambridge University Press.

Romer, Christina (1992). What Ended the Great Depression? Journal of Economic History 52:4, pp.787-784.

Schwartz, Anna (2009). “ Origins of The Financial Market Crises of 2008” Cato Journal 29(1).

Shiller, Robert (2005). Irrational Exuberance (2nd edn.). Princeton, NJ: Princeton Univ. Press.

Shiller, Robert (2008). “Challenging the Crowd in Whispers, Not Shouts.” New York Times, Nov. 1, p. BU5.

Shiller, Robert (2019). Narrative Economics: How Stories Go Viral and Drive Major Economic Events. Princeton University Press.

Sibert, Anne (2003). "Monetary Policy Committees: Individual and Collective Reputations.” Review of Economic Studies, 70:649-665.

Sibert, Anne (2006). “Central Banking By Committee.” International Finance, 9:145-168.

Taylor, John (2007). “ Housing and Monetary Policy.” Remarks at the Federal Reserve Bank of Kansas City, Jackson Hole Economic Policy Symposium: Housing, Housing Finance and Monetary Policy. August.

Velde, Francois (2020). "What Happened to the US Economy During the 1918 Influenza Pandemic? A View Through High-Frequency Data.” Federal Reserve Bank of Chicago Working Paper 2020-11, April.

Viboud, Cecile, Simonsen, Lorne, Fuentes, Rodrigo, Miller, Mark, and Chowell, Gerardo (2015). “Global Mortality Impact of The 1957-59 Influenza Pandemic.” Journal of Infectious Diseases. 